\title{
Response of selected tomato (Solanum lycopersicum L.) cultivars to on-field biotic stress
}

\author{
Ayodele M. Ajayi $\bullet$ Ganiyu F. Hassan
}

Department of Crop, Soil and Pest Management. Federal University of Technology, Akure, P M B, 704, Akure, Ondo State, Nigeria.

*Corresponding author. E-mail: ajayimy25@yahoo.com

Accepted $27^{\text {th }}$ March, 2019.

\begin{abstract}
Pathogenic diseases are major limitations to the cultivation of tomato in the humid rain forest agro-ecological zones (HRAZ). A study was designed to evaluate four cultivars of tomato (DT97/215A, Ajindi-kerewa, Dan-Syria and Roma VF) for tolerance to common field pathogens of the crop in the HRAZ. Analysis of soil preceded land preparation, while seeds and soil for the nursery were sterile. The land area for the field study was $200.60 \mathrm{~m}^{2}$, divided into 12 plots of $7.80 \mathrm{~m}^{2}$. Each plot had 30 tomato stands. The randomized complete block design consisting of three replicates was adopted. Data collected were subjected to statistical analysis. Four diseases, Fusarium wilt, Verticillium wilt, Bacterial wilt and Tomato mosaic were identified with significantly different incidences and severities. Fusarium wilt was the most common, followed by Verticillium wilt, while tomato mosaic was the least. DT97/215A had $61.42 \%$ (incidence) and $28.81 \%$ (severity) of fusarium wilt at 9 weeks after planting, making it the most susceptible. Ajindi-kerewa recorded $51.32 \%$ (incidence) and $16.19 \%$ (severity) in the same period. The least incidences of Fusarium and Verticillium wilt, $0.81 \%$ and $0.31 \%$ respectively, were recorded for Roma VF at 9 wap. No incidence of bacterial wilt and tomato mosaic was recorded for Dan-Syria. Roma VF and Dan-Syria gave 8.29 and 7.95 tonnes/ha yields respectively. Significantly lowest yield, 4.10 tonnes/ha was obtained from DT97/215A. Dan-Syria had the best shelf life, $77.49 \%$ intact fruits at 3 weeks after harvest. Dan-Syria and Roma VF can be recommended for cultivation in the HRAZ.
\end{abstract}

Keywords: Pathogenic diseases, tomato cultivars, tolerance, disease incidence and severity, yield.

\section{INTRODUCTION}

Tomato is named variously as Solanum lycopersicum L, Lycopersicon esculentum Miller and Lycopersicon lycopersicum H. Karten (Peralta et al., 2000; Darwin et al., 2003). The crop is cultivated for its numerous nutritional and health benefits, as well as the provision of employment and income (Pang et al., 2008; Vinha et al., 2014).

According to the FAO report, Nigeria was ranked as the largest producer of tomato in West Africa and the $16^{\text {th }}$ largest producer in the world, with 1.8 million metric tonnes (FAO, 2010). Unfortunately however, demand for tomato and associated products outstrip supply by a wide margin and Nigeria is one of the highest importers of processed tomato (Ugonna et al., 2015). Pathogenic diseases have made the cultivation of the crop a serious challenge, especially in the humid rain forest zone. The high annual rainfall and humidity associated with this zone have brought about an increase in the population of pathogenic microorganisms. Bacterial, fungal and viral diseases, as well as nematode infestations, have all been reported to be major constraints limiting the cultivation of tomato in this zone (Wokoma, 2008; Fajemisin and Fajemisin, 2010; Bello et al., 2015; Terna et al., 2016; Onyekachukwu and Adefoyeka, 2017). Disease severity of between 20 and $100 \%$ has been reported for some of these diseases (Arogundade et al., 2007; Ganiyu et al., 
2016; Onyekachukwu and Adefoyeka, 2017). Consequently, most farmers in the humid rain forest zones in Nigeria have abandoned the cultivation of tomato and the region depends almost entirely on produce from other zones. Bad roads, criminality and insurgency have all contributed to making transportation of produce across regions a risky and dangerous venture, as well as resulting in the rapid deterioration of produce (Idah et al., 2007; Afolabi and Gbadamosi, 2015; Ugonna et al., 2015).

Synthetic chemicals for the management of tomato diseases are available, but the numerous hazards associated with their use has necessitated alternative approaches. Resistant/tolerant varieties of crops are one of these alternatives. This study evaluated four tomato cultivars (DT97/215A, Ajindi-Kerewa, Dan-Syria and Roma VF) for tolerance to common field pathogens. The cultivars were obtained from farmer's field in selected locations across the northern guinea savannah where they thrive with less incidence of diseases.

\section{MATERIALS AND METHODS}

\section{Location of experiment}

The study was carried out at The Federal University of Technology, Akure (FUTA) (longitude $5^{\circ} 06^{\prime} \mathrm{E}$ to $5^{\circ} 38^{\prime} \mathrm{E}$ and between latitude $7^{\circ} 07^{\prime} \mathrm{N}$ to $7^{\circ} 37^{\prime} \mathrm{N}$ ). Mean annual rainfall is above $1,500 \mathrm{~mm}$, while the average temperature is about 22 and $32^{\circ} \mathrm{C}$ for December to February and March to November respectively (Ayeni, 2011; Ogunrayi et al., 2016). Two distinct seasons exist, raining and dry. The raining season is characterised by $85 \%$ humidity, while the dry season has $60 \%$. The planting season is about 8 months, April to October.

\section{Collection of planting materials}

Fruits and seedlings of eight cultivars, obtained from farmers' fields across the agro-ecological zones in Northern Nigeria, where they thrive with less incidence of diseases, were taken to the National Centre for Genetic Resource and Biotechnology (NACGRAB) Ibadan, for identification. Four of the cultivars were successfully identified, namely; DT97/215A, Dan-Syria, Ajindi-Kerewa and Roma VF. The identified cultivars were evaluated in this study.

\section{Seed preparation and raising of nursery}

Seeds for planting were extracted from the fruits of each cultivar, washed with sterile distilled water, air dried and surface sterilised with $1 \%(\mathrm{w} / \mathrm{v})$ Sodium Hypochlorite $(\mathrm{NaOCl})$ for 2 minutes, using the method described by Younesikelaki et al. (2016) with a little modification. Sterilized seeds were sown in humus-rich sterile soil in seed boxes. The cultivars were sown separately and maintained in the nursery for four weeks. Irrigation, with sterile distilled water, and weeding was done as required.

\section{Site selection and soil analysis}

The site of the study was the crop production section of FUTA Teaching and Research Farm (TRF). Soil samples were collected randomly, from topsoil at 0 to $8 \mathrm{~cm}$ depth, from six different locations with the aid of a soil auger having $8.5 \mathrm{~cm}$ diameter. The samples were mixed thoroughly and about $100 \mathrm{~g}$ was weighed and transported to the soil science laboratory of The Department of Crop, Soil and Pest management (CSP) FUTA, for the determination of the physio-chemical properties. Another unit of $20 \mathrm{~g}$ was also weighed out and transported to the pathology laboratory of CSP Department FUTA, for microbial analysis. This was done in a sterile polythene bag in an ice pack.

\section{Physio-chemical analysis of the soil sample}

The physio-chemical analysis of the soil sample was carried out to determine the nutrient status of the study site and its suitability for the cultivation of tomato. Soil sample for analysis was air-dried and passed through 2 $\mathrm{mm}$ sieve to remove large particles, debris and stones. Thereafter, analysis for $\mathrm{pH}$ was done in 1:2 soil to water ratio using Coleman's $\mathrm{pH}$ meter. Organic matter content was determined following the wet oxidation method (Walkley and Black, 1934). Nitrogen (N) content was determined using the Kjeldahl procedure as described by da Silva et al. (2016), Phosphorus (P) by Bray-P1 method (Bray and Kurtz, 1945), while $\mathrm{Ca}$ and $\mathrm{Mg}$ were determined by atomic absorption spectrophotometer (AAS) method (Beatty and Kerber, 1993). Exchange acidity was determined by $\mathrm{KCl}$ extraction method as described by Mclean (1965). Extractive cations of Sodium $(\mathrm{Na})$ and Potassium $(\mathrm{K})$ were determined using flame photometry according to the method of Horwitz (1970). Cations exchange capacity (CEC) was determined using ammonium saturation method (Chapman, 1965). The textural analysis was done by hydrometer method (Gee and Bauder, 1986). Results are presented in Table 1.

\section{Microbial analysis}

The media used for microbial isolation were nutrient agar and Potato Dextrose Agar (PDA). Preparation of the growth media was done following the manufacturer's specifications, while microbial analysis was carried out following a modified method described by Omomowo et al. (2017). One (1) $\mathrm{g}$ of soil sample was added to $9 \mathrm{ml}$ of sterile distilled water in a test-tube and shaken in a mechanical shaker for $15 \mathrm{~min}$, followed by a serial dilution. 
Table 1. Physio-chemical properties/compositions of soil at the study site.

\begin{tabular}{lclc}
\hline Parameters & Values & Parameters & Value \\
\hline $\mathrm{pH}\left(\mathrm{H}_{2} \mathrm{O}\right) 1: 2$ & 5.98 & $\mathrm{Cu}(\mathrm{mg} / \mathrm{kg})$ & 0.08 \\
Total Nitrogen $(\mathrm{g} / \mathrm{kg})$ & 0.51 & $\mathrm{Fe}(\%)$ & 0.19 \\
Total organic carbon $(\%)$ & 0.43 & $\mathrm{Zn}(\mathrm{mg} / \mathrm{kg})$ & 0.31 \\
$\mathrm{P}(\mathrm{mg} / \mathrm{g})$ & 5.06 & $\mathrm{Mn}(\mathrm{mg} / \mathrm{kg})$ & 0.13 \\
$\mathrm{~K}(\mathrm{cmol} / \mathrm{kg})$ & 0.52 & Sand $(\%)$ & 62.80 \\
$\mathrm{Ca}(\mathrm{cmol} / \mathrm{kg})$ & 0.61 & Clay $(\%)$ & 23.20 \\
$\mathrm{Mg}(\mathrm{cmol} / \mathrm{kg})$ & 0.32 & Silt $(\%)$ & 14.00 \\
$\mathrm{Na}(\mathrm{cmol} / \mathrm{kg})$ & 0.48 & CEC $(\mathrm{cmol} / \mathrm{kg})$ & 0.62 \\
\hline
\end{tabular}

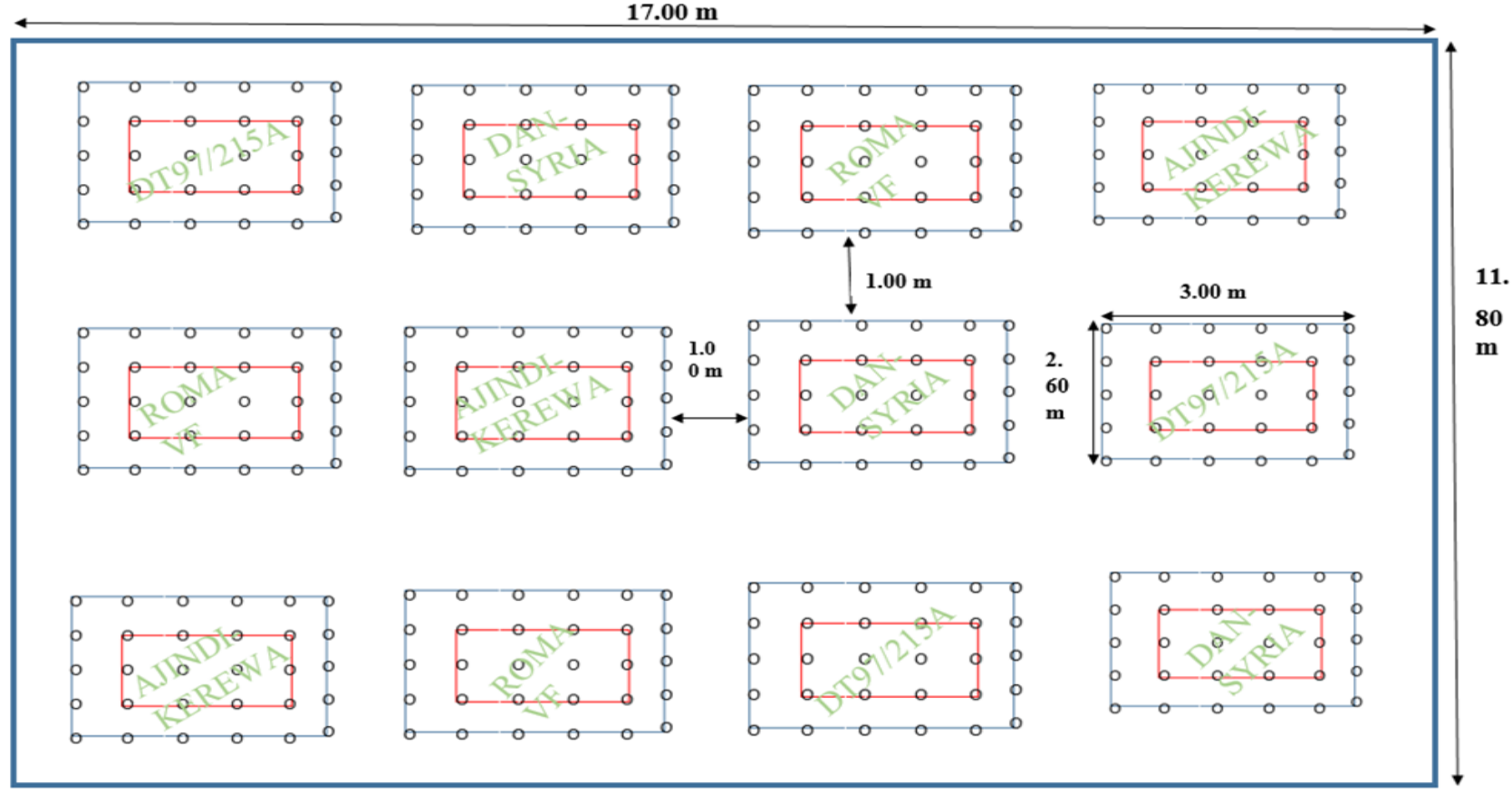

Figure 1. Field layout and experimental design. Legend: 0 o o: Tomato stands;

: Gross plot; Net plot.

A representative sample from $10^{-5}$ was used for isolation of fungi and bacteria. The spread plate inoculation technique was adopted, while bacteria and fungi were isolated in separate Petri-dishes. Treatments were replicated thrice. The PDA for fungal isolation was amended with $0.05 \%$ chloramphenicol antibiotic to prevent bacterial growth, while the nutrient agar was modified with $0.015 \%$ Nystatin to prevent fungal growth. Incubation was done at 37 and $25 \pm 2^{\circ} \mathrm{C}$ for bacteria and fungi respectively, while counting of colonies started from $24 \mathrm{~h}$ after inoculation.

\section{Field layout and experimental design}

The total land area used for the study was $200.60 \mathrm{~m}^{2}$ $(17.00 \mathrm{~m} \times 11.80 \mathrm{~m})$. This was measured out after ploughing, harrowing and ridging. The measured area was divided into 12 plots. Each plot measured $3.00 \mathrm{~m} \times$
$2.60 \mathrm{~m}\left(7.80 \mathrm{~m}^{2}\right)$ gross plot and $1.80 \mathrm{~m} \times 1.30 \mathrm{~m}(2.34$ $\left.\mathrm{m}^{2}\right)$ net plot. The gross plot had 30 tomato stands at 60 $\mathrm{cm} \times 65 \mathrm{~cm}$ spacing. The experimental design adopted was the randomized complete block design (RCBD) with three replications. Each replicate had four plots and the four cultivars of tomato evaluated for this study were allocated randomly to each plot (Figure 1).

\section{Transplant of tomato seedlings to the field}

This was done when the seedlings were 4 weeks old. Tomato seedlings, with small balls of earth around the roots of each stand, were transplanted into shallow holes of $6 \mathrm{~cm}$ depth at one seedling per hole. Transplanting was done late evening in the second week of September, and the experiment was rain-fed. Weeding was done manually as required with a hoe. Staking was also done to provide support for each stand. No disease control 
measure was adopted and fertilizer was not applied.

\section{Data collection and statistical analysis}

\section{Microbial analysis (cfu, sfu/g)}

Data were collected on microbial population per gram of soil and expressed as colony forming unit and sporeforming units, bacteria and fungi, per gram of soil respectively. This was achieved with the aid the following formulas:

$c f u / g=\frac{a \times b}{c}$, bacteria

$s f u / g=\frac{a \times b}{c}$, fungi

Where: $\mathrm{cfu} / \mathrm{g}, \mathrm{sfu} / \mathrm{g}=$ colony forming unit/spore-forming unit per gram of soil sample

$\mathrm{a}=$ total bacterial/ fungal count in culture plate

$\mathrm{b}=$ dilution factor

c $=$ volume of inoculated sample on artificial growth medium

\section{Leaf count}

The total number of leaves on each stand in the net plot was observed visually and counted at 5,8 and 11 weeks after planting (wap).

\section{Plant height (cm)}

Plant height was measured, from the soil surface to the shoot apex, in $\mathrm{cm}$ with a meter rule at 5, 8 and 11 wap.

\section{Disease incidence (\%)}

Data on disease incidence were collected at 7, 9 and 11 wap. The leaves and stems of each plant were examined visually for symptoms of common field diseases of tomato. Samples of infected plants were taken to the pathology lab of CSP Department for isolation and identification of the causal organism. The formula adopted for the determination of disease incidence was;

$d i=\frac{x}{y} \times 100$

Where $d i=$ disease incidence

$x=$ number of diseased tomato stands

$y=$ total number of tomato plant sampled

\section{Disease severity index (\%)}

This was determined with the formula: $d s i=\frac{\sum(a b)}{N K} \times 100$

Where $d s i=$ disease severity index

$a=$ value of disease rating from the disease rating scale

$b=$ number of infected plant stands

$\mathrm{N}=$ total number of plants sampled

$\mathrm{K}=$ highest value on the rating scale

Three of the diseases identified on the field, namely; Fusarium wilt (characterised by wilt, bright yellow and curling of older leaves), bacterial wilt (characterised by wilting of young leaves in hot sun that becomes reversed when at low temperature, sticky and slimy exudates from cut stem) and Verticillium wilt (characterised by wilted shoots, curling downward and falling off of leaves) all had wilt related symptoms, consequently, a single disease rating scale was adopted for them. It consisted of a 0 to 5 scale and was the modified form of the scale presented by Popoola et al. (2012).

$0=$ no symptoms of wilt

$1=1-20 \%$ wilted plant

$2=21-40 \%$ wilted plant

$3=41-60 \%$ wilted plant

$4=61-80 \%$ wilted plant

$5=81-100 \%$ wilted plant $/$ death

A separate rating scale was adopted for the viral disease (tomato mosaic) that was encountered during the study. It was proposed by Bashir and Zubair (2005).

$0=$ no infection

$1=1-10 \%$ of plant infected

$2=11-20 \%$ of plant infected

$3=21-30 \%$ of plant infected

$4=31-50 \%$ of plant infected

$5=$ more than $50 \%$ of the plant infected

\section{Yield (kg and tonnes)}

Matured fruits were harvested, just as the green colour turned slightly red, through hand picking. Fruits harvested from each plot were counted and kept in separate shallow trays and covered with nets. The trays were then kept on the side benches in the crop laboratory of CSP Department. Fruits were checked for spoilage at the point of harvest and on a daily basis for three weeks. Fruit quality was expressed in percentage using the simple formula:

$f q=\frac{a}{b} \times 100$

Where $f q=$ fruit quality $a=$ number of good/spoilt fruits 
Table 2. Microbial composition of soil sample from the study site.

\begin{tabular}{lclc}
\hline Fungi species & Sfu/g & Bacteria species & Cfu/g \\
\hline Aspergillus fumigatus & $7.4 \times 10^{5} \mathrm{a}$ & Beijennckia indica & $5.0 \times 10^{4} \mathrm{a}$ \\
Aspergillus nigger & $7.0 \times 10^{5} \mathrm{ab}$ & Pseudomonas aeruginosa & $4.0 \times 10^{4} \mathrm{~b}$ \\
Mucor mucedo & $6.7 \times 10^{5} \mathrm{abc}$ & Ralstonia solanacearum & $4.1 \times 10^{4} \mathrm{~b}$ \\
Neurospora crissa & $6.3 \times 10^{5} \mathrm{bc}$ & Rhizobium trifolli & $3.6 \times 10^{4} \mathrm{bc}$ \\
Fusarium oxysporum & $6.0 \times 10^{5} \mathrm{C}$ & Pseudomonas fluorescence & $3.1 \times 10^{4} \mathrm{~cd}$ \\
Trichoderma viride & $6.0 \times 10^{5} \mathrm{~cd}$ & Rhizobium japoniicom & $2.9 \times 10^{4} \mathrm{~d}$ \\
Aspergillus flavus & $6.0 \times 10^{5} \mathrm{~cd}$ & Bacillus subtilis & $2.2 \times 10^{4} \mathrm{e}$ \\
Trichoderma harzianum & $5.1 \times 10^{5} \mathrm{de}$ & & \\
Ceratocystis paradoxa & $4.5 \times 10^{5} \mathrm{ef}$ & & \\
Rhizopus stolonifer & $4.2 \times 10^{5} \mathrm{ef}$ & & \\
Verticillium albo-atrium & $4.0 \times 10^{5} \mathrm{f}$ & & \\
Penicillium citratum & $3.0 \times 10^{5} \mathrm{~g}$ & & \\
\hline
\end{tabular}

Note. Means in the same column followed by the same alphabet are not significantly different $(p<0.05)$ according to Tukey's test.

Table 3. Leaf production by the tomato cultivars.

\begin{tabular}{lccc}
\hline \multirow{2}{*}{ Cultivars } & \multicolumn{3}{c}{ Number of leaves/ Weeks after planting } \\
\cline { 2 - 4 } & $\mathbf{5}$ & $\mathbf{8}$ & $\mathbf{1 1}$ \\
\hline Ajindi-Kerewa & $9.89^{\mathrm{a}}$ & $20.80^{\mathrm{a}}$ & $29.99^{\mathrm{a}}$ \\
DT97/215A & $7.96^{\mathrm{b}}$ & $18.07^{\mathrm{b}}$ & $25.89^{\mathrm{b}}$ \\
Dan-Syria & $7.67^{\mathrm{b}}$ & $17.59^{\mathrm{b}}$ & $23.99^{\mathrm{c}}$ \\
Roma VF & $7.18^{\mathrm{c}}$ & $16.36^{\mathrm{b}}$ & $23.86^{\mathrm{c}}$ \\
\hline
\end{tabular}

Note. Means in the same column followed by the same alphabet are not significantly different $(p<0.05)$ according to Tukey's test.

$b=$ total number of harvested fruits.

Data were collected from the net plots and subjected to analysis of variance (ANOVA) using Minitab version 17 software. Mean separation was done using Tukey's test.

\section{RESULTS}

\section{Microbial analysis of the soil sample}

Twelve fungi and seven bacteria were isolated and identified from the study site. With a population of $7.4 \times$ $10^{5}$, Aspergillus fumigatus was the most populous fungus. It was closely followed by $A$. nigger, $7.0 \times 10^{5}$. The population of the two organisms were not significantly different but was significantly higher than the other isolated fungi, except Mucor mucedo and Neurospora crissa. Penicillium citratum had the least population (Table 2). Fusarium oxysporum and Verticillium albo-atrium, the pathogens and incitant of Fusarium wilt and Verticillium wilt respectively, were also isolated. Both had sufficient inoculum in the soil to initiate pathogenesis. F. oxysporum had $6.0 \times 10^{5} \mathrm{sfu} / \mathrm{g}$ while $V$. albo-atrium had $4.0 \times 10^{5} \mathrm{sfu} / \mathrm{g}$ (Table 2). The bacteria species isolated were significantly different in their populations. Ralstonia solanacearum, the causative organism of bacterial wilt, was the second most populous. It had $4.1 \times 10^{4} \mathrm{cfu}$. Beijennckia indica was the most populous, $5.0 \times 10^{4} \mathrm{cfu} / \mathrm{g}$, while Bacillus subtilis had the least population, $2.2 \times 10^{4} \mathrm{cfu} / \mathrm{g}$ (Table 2).

\section{Leaf production}

The four cultivars evaluated differed significantly with regards to the number of leaves produced. Leaf production increased slowly at the first two weeks after transplanting but became rapid at four weeks after transplanting. It then declines steadily with increasing age. At 5 wap, Ajindi-Kererwa had the highest number of leaves, 9.89, while the least number was recorded for Roma VF. The trend continued up to the $11^{\text {th }}$ wap. At this period, Ajindi-Kerewa had 29.99 leaves, the highest, while Roma VF once again had the least at 23.86 (Table 3).

\section{Plant height}

Significant differences existed in the heights recorded for 
Table 4. Height $(\mathrm{cm})$ of the tomato cultivars.

\begin{tabular}{lccc}
\hline \multirow{2}{*}{ Cultivars } & \multicolumn{3}{c}{ Plant height/ Weeks after planting } \\
\cline { 2 - 4 } & $\mathbf{5}$ & $\mathbf{8}$ & $\mathbf{1 1}$ \\
\hline Ajindi-Kerewa & $36.04^{\mathrm{a}}$ & $52.06^{\mathrm{a}}$ & $63.03^{\mathrm{a}}$ \\
DT97215A & $27.08^{\mathrm{c}}$ & $47.01^{\mathrm{b}}$ & $60.50^{\mathrm{b}}$ \\
Dan-Syria & $29.41^{\mathrm{b}}$ & $46.93^{\mathrm{b}}$ & $59.03^{\mathrm{c}}$ \\
Roma VF & $30.34^{\mathrm{b}}$ & $42.71^{\mathrm{c}}$ & $51.43^{\mathrm{d}}$ \\
\hline
\end{tabular}

Note. Means in the same column followed by the same alphabet are not significantly different $(p<0.05)$ according to Tukey's test.

Table 5. Disease incidences (\%) in the tomato cultivars.

\begin{tabular}{|c|c|c|c|c|c|c|c|c|c|c|}
\hline \multirow{3}{*}{ Cultivars } & \multicolumn{10}{|c|}{ Weeks after planting } \\
\hline & \multicolumn{2}{|c|}{7} & \multicolumn{4}{|c|}{9} & \multicolumn{4}{|c|}{11} \\
\hline & VW & FW & VW & FW & BW & TM & vw & FW & BW & TM \\
\hline DT97/215A & $2.14^{a}$ & $22.53^{a}$ & $8.46^{\mathrm{a}}$ & $61.42^{\mathrm{a}}$ & $2.57^{b}$ & $0.00^{\mathrm{a}}$ & $4.31^{\mathrm{a}}$ & $52.97^{a}$ & $3.47^{a}$ & $0.00^{\mathrm{b}}$ \\
\hline Ajindi-Kerewa & $1.21^{b}$ & $13.54^{\mathrm{b}}$ & $4.40^{\mathrm{b}}$ & $51.32^{\mathrm{b}}$ & $1.50^{c}$ & $0.70^{\mathrm{a}}$ & $2.16^{b}$ & $39.08^{b}$ & $1.10^{\mathrm{b}}$ & $1.27^{\mathrm{a}}$ \\
\hline Dan-Syria & $0.00^{c}$ & $3.43^{c}$ & $0.77^{\mathrm{c}}$ & $16.32^{c}$ & $0.00^{c}$ & $0.00^{\mathrm{a}}$ & $0.70^{c}$ & $15.92^{c}$ & $0.00^{\mathrm{b}}$ & $0.00^{\mathrm{b}}$ \\
\hline Roma VF & $0.00^{c}$ & $0.00^{d}$ & $0.31^{\mathrm{c}}$ & $0.81^{d}$ & $7.24^{\mathrm{a}}$ & $1.10^{\mathrm{a}}$ & $0.65^{c}$ & $1.21^{\mathrm{d}}$ & $2.77^{\mathrm{a}}$ & $0.00^{\mathrm{b}}$ \\
\hline
\end{tabular}

Note. Means in the same column followed by the same alphabet are not significantly different $(p<0.05)$ according to Tukey's test. Legend: $\mathrm{VW}=$ Verticillium wilt; $\mathrm{FW}=$ Fusarium wilt; $\mathrm{BW}=$ Bacterial wilt; $\mathrm{TM}=$ Tomato mosaic

the four cultivars, with a clear trend of steady increase with increasing age. Two of the cultivars, namely; Roma VF and DT97/215A had different peak growth periods and each had least heights at different points during their growth cycle. DT97/215A had the least height, $27.08 \mathrm{~cm}$ at 5 wap, while Roma VF had the least, 42.71 and, 51.43 $\mathrm{cm}$ at 8 and 11 wap respectively (Table 4). AjindiKerewa, on the other hand, exhibited consistency in height and was significantly the tallest at 5,8 and 11 wap with $36.04,52.06$ and $63.03 \mathrm{~cm}$ plant heights respectively. Dan-Syria and DT97/215A were not significantly different at 8 wap (Table 4).

\section{Disease incidence}

The first symptom of infection, wilted portion on the shoot of a single stand, was observed on DT97/215A and data collection on disease incidence and severity stated by the $7^{\text {th }}$ wap. Data were collected on Verticillium and fusarium wilts (Table 5). At 9 wap, incidences of bacterial wilt and tomato mosaic disease were observed and recorded, in addition to Verticillium and fusarium wilts. Fusarium wilt was the most common infection, and DT97/215A was the most susceptible. The values obtained for disease incidences were significantly different across the four diseases and the four tomato cultivars. DT97/215A had $22.53,61.42$ and $52.975 \%$ disease incidence of fusarium wilt at 7, 9 and 11 wap respectively (Table 5). The cultivar was also the most susceptible to Verticillium wilt. Roma
VF had the least susceptibility to Fusarium and Verticillium wilt among the four cultivars. Ajindi-Kerewa was the second most susceptible to Fusarium and Verticillium wilts, with a disease incidence of 51.32 and $4.40 \%$ at 9 wap respectively (Table 5 ). These values were significantly higher than those obtained for DanSyria and Roma VF. Dan-Syria had no incidences of bacterial wilt and tomato mosaic all through the period of its growth cycle (Table 5). On a general note, infection from the diseases encountered during the course of this study progressed slowly and attained a peak at 9 wap, after which it declined gradually with the increasing age of the tomato cultivars.

\section{Disease severity}

Fusarium wilt was the most severe infection, and DT97/215A being the most susceptible, had severity values of $10.09 \%, 28.81 \%$ and $20.41 \%$ at 7,9 and 11 wap respectively. These values were significantly higher than those obtained for the other cultivars (Table 6). Bacterial wilt was the second most severe. The highest severity value recorded for it was $4.59 \%$. This was obtained from Roma VF at 9 wap. It was significantly higher than the other cultivars (Table 6). Tomato mosaic was the least severe. The highest severity value recorded was for Ajindi-Kerewa $(0.66 \%)$ at 11 wap. There was no significant difference in the severity of Tomato mosaic disease among the four cultivars (Table 6). 
Table 6. Disease severity (\%) in the tomato cultivars.

\begin{tabular}{|c|c|c|c|c|c|c|c|c|c|c|}
\hline \multirow{3}{*}{ Cultivars } & \multicolumn{10}{|c|}{ Weeks after planting } \\
\hline & \multicolumn{2}{|c|}{7} & \multicolumn{4}{|c|}{9} & \multicolumn{4}{|c|}{11} \\
\hline & Vw & FW & VW & FW & BW & TM & VW & FW & BW & TM \\
\hline DT97/215A & $0.74^{a}$ & $10.09^{a}$ & $1.55^{\mathrm{b}}$ & $28.81^{a}$ & $1.04^{b}$ & $0.00^{\mathrm{a}}$ & $0.88^{\mathrm{ab}}$ & $20.41^{a}$ & $2.53^{a}$ & $0.00^{\mathrm{a}}$ \\
\hline Ajindi-Kerewa & $0.50^{\mathrm{b}}$ & $3.13^{\mathrm{b}}$ & $2.83^{a}$ & $16.19^{b}$ & $1.05^{\mathrm{b}}$ & $0.30^{\mathrm{a}}$ & $1.94^{\mathrm{a}}$ & $15.28^{b}$ & $0.92^{b}$ & $0.66^{\mathrm{a}}$ \\
\hline Dan-Syria & $0.00^{\mathrm{c}}$ & $1.51^{\mathrm{C}}$ & $0.51^{\mathrm{c}}$ & $6.09^{c}$ & $0.00^{c}$ & $0.00^{\mathrm{a}}$ & $0.44^{\mathrm{b}}$ & $2.14^{\mathrm{c}}$ & $0.00^{c}$ & $0.00^{\mathrm{a}}$ \\
\hline Roma VF & $0.00^{c}$ & $0.00^{d}$ & $0.21^{c}$ & $0.37^{d}$ & $4.59^{a}$ & $0.61^{a}$ & $0.48^{\mathrm{b}}$ & $0.31^{d}$ & $1.93^{\mathrm{a}}$ & $0.00^{\mathrm{a}}$ \\
\hline
\end{tabular}

Note. Means in the same column followed by the same alphabet are not significantly different $(p<0.05)$ according to Tukey's test. Key: VW = Verticillium wilt; $\mathrm{FW}=$ Fusarium wilt; $\mathrm{BW}=$ Bacterial wilt; $\mathrm{TM}=$ Tomato mosaic

Table 7. Yields ( $\mathrm{kg} /$ tonnes) from the tomato cultivars.

\begin{tabular}{lccc}
\hline \multirow{2}{*}{ Cultivars } & \multicolumn{3}{c}{ Yield } \\
\cline { 2 - 4 } & No. of fruits/plot & Fruit weight/plot (kg) & Yield/ha (tonnes) \\
\hline DT97/215A & $97.33^{\mathrm{c}}$ & $0.96^{\mathrm{b}}$ & $4.10^{\mathrm{b}}$ \\
Ajindi-Kerewa & $100.74^{\mathrm{c}}$ & $1.24^{\mathrm{b}}$ & $5.31^{\mathrm{b}}$ \\
Dan-Syria & $192.54^{\mathrm{a}}$ & $1.86^{\mathrm{a}}$ & $7.95^{\mathrm{a}}$ \\
Roma VF & $167.08^{\mathrm{b}}$ & $1.94^{\mathrm{a}}$ & $8.29^{\mathrm{a}}$ \\
\hline
\end{tabular}

Note. Means in the same column followed by the same alphabet are not significantly different $(p<$ 0.05 ) according to Tukey's test.

\section{Yield and yield quality}

Yields were significantly different among the cultivars. The highest number of fruits, 192.54, was harvested from Dan-Syria. This was followed by Roma VF with 167.08 . The two values were not significantly different but were significantly higher than Ajindi-Kerewa and DT97/215A that produced 100.74 and 97.33 fruits respectively (Table 7). Analysis of fruit weight showed a significant difference among the cultivars. Roma VF had the highest value per plot, $1.94 \mathrm{~kg}$, while DT97/215A had the least value, 0.96 $\mathrm{kg} /$ plot (Table 7). In terms of yield per hectare, DT97/215A and Ajindi-Kerewa were not significantly different, 4.10 and 5.31 tonnes/ha respectively. Roma VF, with 8.29 tonnes/ha, was significantly higher than Ajindi-Kerewa and DT97/215A (Table 7). The yield quality of the four cultivars differs significantly (Figure 2). DanSyria had the lowest percentage spoilage and the longest shelf live. Exactly $77.45 \%$ of harvested fruits remain in good condition three weeks after harvest. DT97/215A had the poorest fruit quality. At three weeks after harvest $41.79 \%$ of fruits were already lost (Figure 2 ).

\section{DISCUSSION}

The physio-chemical analysis results of soil from the study site showed that it was sandy clay loam alfisol. This means it is well drained and does not encourage waterlogging. The $\mathrm{pH}$ value of 5.98 matches the range recommended by Oyinlola and Jinadu (2012) as well as
Taun (2015). The nutrient status as well as the other physical properties of the study site is also in line with their recommendations. The incidences of bacterial, vertivillium and fusarium wilts may be due to the presence of inocula of the pathogens at the study site as reveiled by microbial analysis of soil sample. The infection process pathogenicity and effects of these pathogens on the growth and yield of tomato have been studied extensively by scholars (Patrice and Timur, 2008; Wokoma, 2008; Bakeer et al., 2016). Fusarium wilt was the most severe infection with severity percentage of $51.56 \%$ recorded for DT97/215A. Report from previous research works corroborates this finding. Different incidence and severity percentages of the disease have been recorded for different cultivars of tomatoes (Akran et al., 2014; Anonion et al., 2017). Roma VF had low incidence and severity of both fusarium and verticillium wilts. This is most likely due to the fact that it has resistance genes to the pathogens that incite both diseases. This, in addition to the fact that the fruits were bigger in size than the other cultivars, probably explains why it gave the highest yield per ha. Ojo et al. (2013) had reported a similar finding in a study carried out in the southern guinea savannah of Nigeria. The poor yield recorded for DT97/215A is most likely due to the high incidence and severity of fusarium and verticillium wilt. Olaniyi et al. (2010) reported earlier on the poor agronomic performance and yield of the cultivar in a study involving six other cultivars. The fruits of Dan-Syria were smaller, compared to Roma VF, but it recorded the best shelf life with the least percentage of spoilage at 


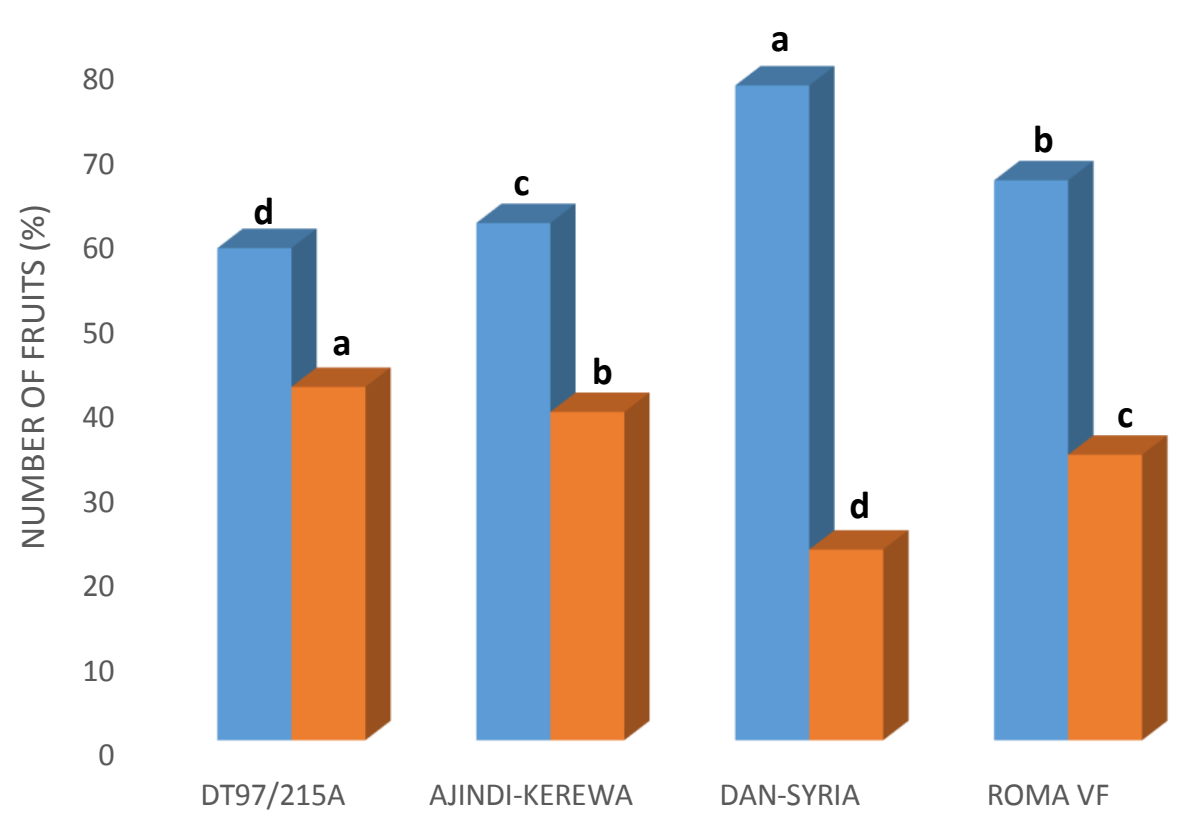

CULTIVARS

Figure 2. Yield quality at 3 weeks after harvest.

three weeks after harvest. This, in addition to the good flavour of the fruits, a fact reported earlier by Kabura et al. (2009), stands it apart from the other cultivars evaluated.

\section{CONCLUSION}

Results from this study showed that Roma VF exhibited least susceptibility to the most common fungal diseases at the site of the study. It also gave the best yield. No incidence of bacterial wilt was recorded for Dan-Syria, and it yield was second best. In addition, Dan-Syria had best flavour and shelf-life. The information provided by this study can be adopted in carrying out further trials in locations with similar soil and climatic conditions. The two cultivars may form an important component in an integrated disease management plan for tomato plants.

\section{REFRENCES}

Afolabi JA, Gbadamosi KT (2015). Road Trafic Crashes in Nigeria: Causes and Consequences. The Int. J. Transp. Logistics 17(42):4049.

Akran W, Anjum T, Ahmed A (2014). Basal susceptibility of Tomato Varieties Against Different Isolates of Fusarium oxysporum f. $\mathrm{sp}$ lycopersici. Int. J. Agric. Biol. 16:171-176.

Anonion A, Tsolakidu M, Stringlis IA, Pantelides IS (2017). Rhizosphere Microbiome Recruited from a Suppressive Compost Improves Plant Fitness and Increase Protection Against Vascular Wilt Pathogens of Tomato. Front. Plant Sci. 8:1-16.
Arogundade O, Balogun OS, Fawole OB (2007). Incidence and Severity of Common Viral and fungal diseases of Dry Season Tomato Crop in Southern Guinea Savannah Agro-ecology. Agrosearch 9(1\&2):53-60.

Ayeni A (2011). Malaria Morbidity in Akure, South West Nigeria: A Temporal Observation in a Climate Change Scenario. Trends Appl. Sci. Res. 6: 488-494.

Bakeer ART, El-Muhamedy RSR, Saied NM, Add-EL-Kareem F (2016). Field Suspression of Fusarium Soil-Borne Diseases of Tomato Plant by the Combined Application of Bio-Agents and Chitosan. Brit. Biotechnol. J. 13(3):1-10.

Bashir M and Zubair M (2005). Studies on Viral Diseases of Major Pulse Crops and Identification of Resistant Sources. Technical Annual Report (April, 2004-June 2005) of APL Project. Crop Science Institute, National Agricultural Research Centre, Islamabad. p.169.

Beatty RD, Kerber JD (1993). Concepts, Instrumentation and Techniques in Atomic Absorption Spectrophotometry (second ed.), The Perkin-Elmer corporation, Nortwalk CT, USA. p. 96.

Bello TT, Fawole B, Abiodun C (2015). Susceptibility of Seven Varieties of Pepper and Tomato to Root-Knot Knot Nematodes (Meloidogyne spp) in Ibadan, Nigeria. IOSR J. Agric. Vet. Sci. 8(10):79-82.

Bray RH, Kurtz LT (1945). Determination of Total, Organic and Available forms of Phosphorus in Soils. Soil Sci. 59:39-45.

Chapman HD (1965). Cation-exchange Capacity. In: CA Black (ed). Methods of Soil Analysis-Chemical and Microbiological Properties. Agronomy 9:891-901.

Darwin SC, Knap S, Peralta IE (2003). Taxonomy of Tomatoes in the Galapagos Islands: Nature and Induced Species of Solanum Section Lycopersicon (Solanaceae). Syst. Biodivers. 1(1):29-53.

da Silva ET, Detmann E, Fraudo MO, Palma MNN, Rocha GC (2016). Evaluation of Digestion Process in Kjedahl Method to Quantify Total Nitrogen in Analysis Applied to Animal Nutrition. Anim. Sci. 38(10):45-51.

Fajemisin AA, Fajemisin OB (2010). An overview of Bacterial Wilt Disease of Tomato in Nigeria. Agric. J. 5(4):242-247.

Food and Agricultural Organization of the United Nations (FAO) 
(2010). FAOSTAT. Available: http://faostat.fao.org/default.aspx.

Ganiyu SA, Popoola AR, Enikuomehin OA, Bodunde JG (2016). Tube Grafting Reduces Incidence and Severity of Bacterial Wilt in Tomato Cultivars in Abeokuta, Nigeria. J. Agric. Sci. Environ. 16(1):96-104.

Gee GW, Bauder TW (1986). Particle Size Analysis. In: Methods of Soil Analysis, P. A Klute (ed.). $2^{\text {nd }}$ Ed. Am. Soc. Agron. Madison, WI, 9:383-411.

Horwitz W (1970). Official Methods of Analysis of the Association of Official Analytical Chemists. $11^{\text {th }}$ ed. Washinton, DC. p. 784

Idah PA, Ajisegiri ESA, Yisa MG (2007). Fruits and Vegetable Handling AND Transportation in Nigeria. Assumption Univers. J. Technol. 10(3):175-183.

Kabura BH, Odo PE, Abubakar A (2009). Performance of some Tomato (Lycopersicon esculentum. Mill) Varieties Under Heat Period in Northern Nigeria. J. Agron. 8:45-48.

Mclean EO (1965). Aluminium. In: Methods of Soil Analysis. American Science Agronomy, Madison, Winsconsin. pp. 978-998.

Ogunrayi OA, Akinseye FM, Goldberg V, Berhofer C (2016). Descriptive Analysis of Rainfall and Trends over Akure, Nigeria. J. Geogr. Reg. Plan. 9(11):195-202.

Ojo GOS, Ekoja EE and Ukpoju OP (2013). Evaluation of Tomato (Lycopersicon lycopersicum Mill) for Fruit Yield and Yield Components in the Southern Guinea Savannah Ecology of Nigeria. Int. J. Agron. Agric. Res. 3(3):1-5.

Olaniyi JO, Akanbi WB, Adejumo TA, Akande OG (2010). Growth, Fruit Yield and Nutritional Quality of Tomato Varieties. Afr. J. Food Sci. 4(6):398-402.

Omomowo IO, Salami AO, Olaniyi TI (2017). Preliminary Study on Climate Seasonal and Spatial Variations on the Abundance and Diversity of Fungi Species in Natural Plantation Ecosystem of Ile-ife, South West, Nigeria. Afr. J. Environ. Sci. Technol. 11(1):33-44.

Onyekachukwu OA, Adefeoye OA (2012). Fusarium Wilt Disease of Tomato: Screening for Resistance and In-vitro Evaluation of Botanicals for Control, the Nigeria Case. Journal of Microbiology, Biotechnol. Food Sci. 7(1):32-36.

Oyinlola EY, Jinadu SA (2012). Growth, Yield and Nutrient Concentrations of Tomato as Affected by Soil Textures and Nitrogen. Asian J. Agric. Res. 6(1):39-45.
Pang Y, Zhang Y, Ye J (2008). Determination of Phenolic Compounds and Associated Acids in Different Fractions of Tomato by Capillary Electrophoresis with Electrochemical Detection. J. Agric. Food Chem. 56:1838-1844.

Patrice GC, Timur MM (2008). Bacterial wilt of Tomato. USDA-NRI Project: R. solanacearum Race 3 Biover 2: Detection, Exclusion and Analysis of Selected Agents. Education Module. p. 11.

Peralta IE, Spooner DM (2000). Classification of Wild Tomato: A Review. Tomato 28(1):45-54.

Popoola AR, Ganiyu SA, Durojaiye SO (2012). Antimicrobial Efficacy of Thymol in the Management of Bacterial Wilt of Tomato. J. Agric. Sci. Environ. 12(1):95-103

Terna TP, Okoro JK, Bem AA, Okogba Jl, Waya Jl (2016). Incidence and Severity of Diseases Associated with Rain-fed Tomatoes in Benue State, Nigeria.IOSR J. Agric. Vet. Sci. 9(4):59-65.

Taun MH (2015). Agronomic Requirements and Production Methods of Tomato in Red River Delta of Vietnam. J. Trop. Crop Sci. 2(1):33-38.

Ugonna CU, Jolaoso MA Onwualu AP (2015). Tomato Value Chain in Nigeria: Issues, Challenges and Strategies. J. Sci. Res. Report. 7(7):501-515.

Vinha AE, Alves RC, Sergio VP, Castro A, Anabela MBC, Olivera PP (2014). Effect of Peel and Seed Removal on the Nutritional Value and Anti-oxidant Activity of Tomato (Lycopersicum esculentum. L) Fruit. LWT-Food Sci. Technol. 55:192-202.

Walkley A, Black IA (1934). An examination of the Degtjareff Method for Determining Soil Organic Matter and Proposed Modification of the Chromic acid Titration Method. Soil Sci. 37:29-38.

Wokoma EC (2008). Preliminary Reports on Diseases of Tomato in Choba, River State. J. Appl. Sci. Environ. Manage. 12(3):117-121.

Younesikelaki FS, Ebrahimzadeh MH, Desfardi MK, Banala M, Marka R, Nanna RS (2016). Optimisation of Seed Surface Sterilisation Method and In-vitro Seed Germination in Althaea officinalis. (L) - An Important Medicinal Herb. Indian J. Sci. Technol. 9(28):1-6. 